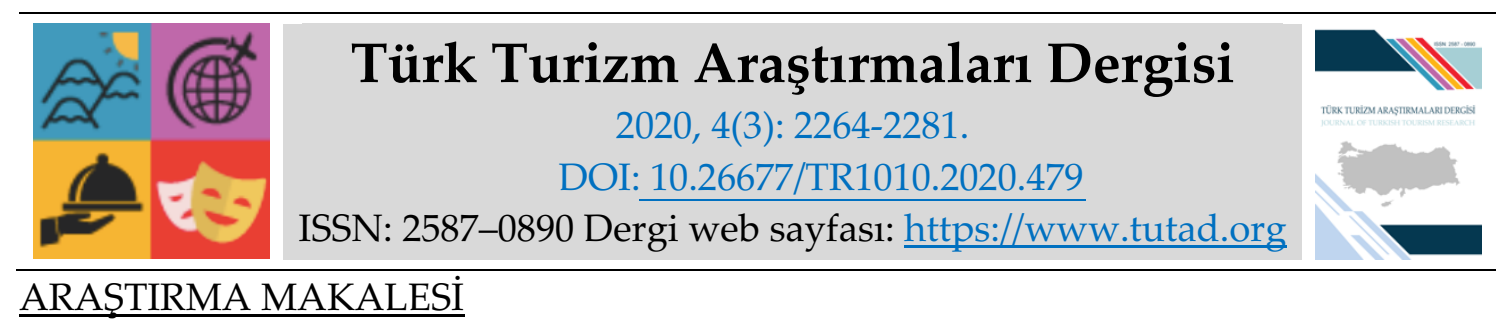

\title{
Otel İşletmelerinde Marka Denkliğinin Müşteri Memnuniyeti Üzerindeki Etkisi: Güven Değişkeninin Aracı Rolü
}

Dr. Öğr. Üyesi Abdullah USLU, Akdeniz Üniversitesi, Manavgat Turizm Fakültesi, Antalya, eposta: auslu@akdeniz.edu.tr ORCID: https://orcid.org/0000-0002-3660-7096

Dr. Öğr. Üyesi Gözde Seval ERGÜN, Akdeniz Üniversitesi, Manavgat Turizm Fakültesi, Antalya, e-posta: gates@akdeniz.edu.tr ORCID: https://orcid.org/0000-0002-5697-626X

Dr. Öğr. Üyesi Ali Naci KARABULUT, Muğla Sıtkı Koçman Üniversitesi, Fethiye İşletme Fakültesi, Muğla, e-posta: alinacikarabulut@gmail.com

ORCID: https://orcid.org/0000-0001-9156-1732

Öz

Marka kavramının, tüketici karar alma sürecinin önemli belirleyicilerinden birisi olduğu bilinmektedir. Turizm endüstrisinin temel yapıtaşlarından olan otel işletmeleri de müşterileriyle sürdürülebilir ilişkiler geliştirip rekabette ayakta kalabilmek adına marka yönetimine ihtiyaç duymaktadır. Soyut bir kavram olan markanın yönetilmesi, markanın hedef müşteriler açısından taşıdığı değerin anlaşılmasını ve dolayısıyla marka denkliği ile müşteri ilişki kalitesi boyutlarının bir arada ele alınmasını gerektirmektedir. Bu çalışma, marka denkliği boyutlarının, müşteri ilişki kalitesi alt boyutları olan güven ve memnuniyete etkisini belirleyebilmek ve aralarındaki ilişkide güvenin aracı etkisini test edebilmek amacıyla gerçekleştirilmiştir. Araştırma Fethiye'deki otel işletmelerine gelen yabancı turistlerden toplanan 302 anket üzerinden gerçekleştirilmiştir. SPSS ve Smart PLS istatistiki programları kullanılarak AFA, DFA, Path analizleri ile Sobel testi yapılmıştır. Araştırmanın sonucunda otel marka denkliğinin, müşteri memnuniyeti ve güven üzerinde anlamlı ve pozitif etkisi olduğu tespit edilmiştir. Ayrıca otel marka denkliği ile müşteri memnuniyeti arasında, güven değişkeninin de aracılık rolünün bulunduğu belirlenmiştir.

Anahtar Kelimeler: Otel Marka Denkliği, İlişki Kalitesi, Müşteri Memnuniyeti, Güven, Fethiye. Makale Gönderme Tarihi: 30.03 .2020

Makale Kabul Tarihi: 02.07.2020

Önerilen Atıf:

Uslu, A., Ergün, G. S. ve Karabulut, A. N. (2020). Otel İşletmelerinde Marka Denkliğinin Müşteri Memnuniyeti Üzerindeki Etkisi: Güven Değişkeninin Aracı Rolü, Türk Turizm Araştırmaları Dergisi, 4(3): 2264-2281.

(C) 2020 Türk Turizm Araştırmaları Dergisi. 


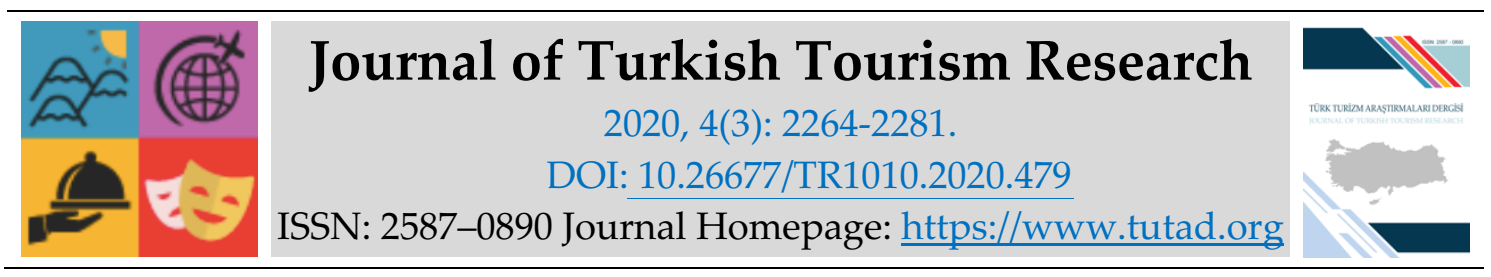

RESEARCH PAPER

\title{
The Effect of Brand Equivalence on Customer Satisfaction in Hotel Businesses: The Mediating Role of Trust Variable
}

Assistant Prof. Dr. Abdullah USLU, Akdeniz University, Manavgat Faculty of Tourism, Antalya, e-mail: auslu@akdeniz.edu.tr

ORCID: https://orcid.org/0000-0002-3660-7096

Assistant Prof. Dr. Gözde Seval ERGÜN, Akdeniz University, Manavgat Faculty of Tourism, Antalya, e-mail: gates@akdeniz.edu.tr ORCID: https://orcid.org/0000-0002-5697-626X

Assistant Prof. Dr. Ali Naci KARABULUT, Muğla Sıtkı Koçman University, Fethiye Faculty of Business, Muğla, e-mail: alinacikarabulut@gmail.com

ORCID: https://orcid.org/0000-0001-9156-1732

\begin{abstract}
It is known that the concept of the brand is one of the important determinants of the consumer decisionmaking process. Hotel businesses, which are the main building blocks of the tourism industry, also need brand management to develop sustainable relationships with their customers and survive in the competition. Managing the brand, which is an abstract concept, requires an understanding of the value of the brand in terms of target customers, and therefore the brand equivalence and customer relationship quality dimensions to be discussed together. This study was carried out to determine the effect of brand equivalence dimensions on customer satisfaction quality sub-dimensions, trust and satisfaction, and to test the mediating effect of trust in the relationship between them. The research was carried out through 302 questionnaires collected from foreign tourists coming to the hotel businesses in Fethiye. EFA, CFA, Path analyzes and Sobel tests were performed using SPSS and Smart PLS statistical programs. As a result of the research, it has been determined that hotel brand equivalence has a significant and positive effect on customer satisfaction and trust. Also, it is determined that the trust variable has a mediator role between hotel brand equivalence and customer satisfaction.
\end{abstract}

Keywords: Hotel Brand Equity, Relationship Quality, Customer Satisfaction, Trust, Fethiye.

Received: 30.03 .2020

Accepted: 02.07.2020

Suggested Citation:

Uslu, A., Ergün, G. S. and Karabulut, A. N. (2020). The Effect of Brand Equivalence on Customer Satisfaction in Hotel Businesses: The Mediating Role of Trust Variable, Journal of Turkish Tourism Research, 4(3): 22642281.

(C) 2020 Türk Turizm Araştırmaları Dergisi. 


\section{Gíriş}

Markalaşma, pazarlama literatüründe 1940'lardan beri yer almasına (Guest, 1942) ve geniş bir geçmişe sahip olmasına rağmen (Aaker ve Joachimsthaler, 2000), konunun ancak son yıllarda turizm alanındaki araştırmacılarca dikkate alındığı görülmektedir (Pike, 2009; Horng, Liu, Chou ve Tsai, 2012; Liu ve Chou, 2016; Pike ve Bianchi, 2016; Nassar, 2017; González-Mansilla, Berenguer-Contrí ve Serra-Cantallops, 2019). Bu bağlamda, marka değerinin turizm alanındaki etkilerini anlamak için daha fazla araştırma yapılmasına ihtiyaç duyulmaktadır (San Martin vd., 2019). Son birkaç yılda çok ilerleme kaydedilmiş olsa da özellikle otel marka denkliği teorisinin geliştirilmesi gerektiği göz ardı edilmemelidir (Bailey ve Ball, 2006).

Kotler (2000: 404) "markayı" şu şekilde tanımlamaktadır; "Bir satıcı veya satıcı grubunun mal veya hizmetlerini tanımlayan ve rakiplerinden farklılaştıran bir isim, terim, işaret, sembol, tasarım veya bunların bir kombinasyonudur." Markalaşma, işletmelerin tüketicilerin zihinlerindeki mal veya hizmetleri tanımlamaları için etkili bir araç olmakta ve işletme performansını artırmak için yaygın olarak kullanılan bir pazarlama stratejisi olarak kabul edilmektedir (Hsu, Oh ve Assaf, 2011; Liu vd., 2012; Liu vd., 2017). Bununla beraber markalaşma, işletmelerin fiyat dışı unsurlarla rekabet etmelerini sağlamakta (Bailey ve Ball, 2006) ve hizmetlere müşteriler açısından bir katma değer sağlamaktadır. Bu iddia, küresel ve oldukça rekabetçi doğasıyla karakterize edilen otelcilik sektörü için özel bir önem taşımaktadır. Günümüzde turizm sektöründe, tüketicilerle güçlü duygusal ve davranışsal bağlar kurmak için sağlam bir marka oluşturmak şart hale gelmiştir. Ayrıca, konunun otelcilik sektörü gibi hizmet işletmeleri bağlamında ele alınması, somut ürünlere göre daha da önemli kabul edilmiş ve otel pazarlamasının geliştirilmesinde anahtar bir unsur olarak görülmeye başlanmıştır (GonzálezMansilla, 2019). Doğru markalaşma, örgütsel başarı için de hayati bir önem taşımaktadır (Huang ve Cai, 2015). Marka yöneticileri genellikle güçlü bir marka oluşturmaktan ve sürdürmekten sorumlu tutulmakta bununla beraber marka değerini ölçmenin yollarını da bulmak zorunda kalmaktadır (Kayaman ve Arasli, 2007). Başarılı markalaşma, artan kar marjları, kriz sonrasında devam eden müşteri sadakati ve fiyat değişikliklerinden etkilenmeyen müşteri tepkileri de dahil olmak üzere birçok fayda sağlamaktadır (Kim vd., 2003).

Bu makalenin amacı, literatür taraması temelinde müşteri temelli marka denkliği konusunu kavramsal açıdan irdelemek ve bunu otel işletmelerinin misafirleri açısından ampirik olarak test etmektir. Ayrıca bu çalışma, otel marka denkliğinin, müşteri memnuniyetini ve güvenini nasıl etkilediğini açıklayarak literatürdeki boşluğu da doldurmayı amaçlamaktadır.

Araştırmada genel olarak marka denkliği ve ana boyutları üzerine kavramsal bir çerçeve sunulmakta ve buna göre araştırma hipotezleri önerilmektedir. Ardından veri toplama ve yapı geçerliliği ile ilgili metodolojiyi kapsamakta bunun yanında veri analizi ve bulgular üzerine odaklanmaktadır. Son olarak ise sonuç ve tartışma kapsamında yapılan çıkarımları ve gelecekteki araştırmalara sunulan önerileri içine almaktadır.

\section{KAVRAMSAL ÇERÇEVE}

Marka denkliğini geliştirmeye yönelik araştırma yapmanın önemi, pazarlama stratejisi ve rekabet avantajı ile güçlü ilişkisi (Keller, 2009) nedeniyle son dönemde turizm literatüründe sıklıkla üzerinde durulmaktadır (Seric vd., 2017). Bazı çalışmalara göre markalı otellerin diğerlerine göre daha iyi performans gösterdiği iddia edilmekte (Forgacs, 2003) ve aynı zamanda lüks otellerin marka değeri başarısı ile finansal performansları arasında pozitif bir ilişki olduğu da söylenmektedir (Kim ve Kim, 2005). 
Literatürde marka denkliğine ilişkin üç farklı bakış açısı bulunmaktadır. Bunlar; finansal temelli yaklaşım, müşteri temelli yaklaşım ve karma yaklaşımdır (Bailey ve Ball, 2006; Kim vd., 2003; Kim ve Kim, 2005). Finansal temelli yaklaşım, markanın maddi imkânlarından ve somut değerlerinden hareketle marka denkliğini açıklamaktadır (Simon ve Sullivon, 1993). Ancak finansal temelli yaklaşım markanın gücünü oluşturan tüm faktörleri içermediği ve müşteri bakış açısını göz ardı ettiği için eleştirilmektedir (Koçoğlu ve Aksoy, 2007: 73). Müşteri temelli marka değeri ise, herhangi bir markaya karşı oluşan tüketici tepkisinin değerlendirilmesidir (Chang vd., 2008). Bu yaklaşımda markanın ancak tüketiciye değer sağladığı zaman değer üreteceği düşünülmektedir (Aaker, 1991; Keller, 1993). Müşteri temelli marka denkliği, her ikisi de aynı pazarlama uyaranlarına ve ürün özelliklerine sahip olduğunda, odak marka ile markasız ürün arasında tüketicilerin verdiği farklı tepkiler olarak kabul edilmektedir (Yoo ve Donthu, 2001). Son olarak, karma yaklaşım markanın hem pazar gücünü hem de finansal değerini benimsemektedir (Seric vd., 2017).

Marka denkliğine ilişkin bu farklı bakış açıları arasında hem genel marka değeri hem de özellikle otel işletmelerinin marka değerini ele alan araştırmalarda müşteri temelli bakış açısına vurgu yapıldığı görülmektedir (Seric vd., 2017). Marka denkliğinin müşteri bakış açısı ile kavramsal hale getirilmesinin hem pazarlama stratejileri hem de yönetimde karar verme süreci için faydalı olacağ1 düşünülmektedir (Keller, 1993).

Müşteri temelli marka denkliği ile ilgili en çok referans gösterilen Aaker (1991) ve Keller (1993) tarafından geliştirilen iki farklı model bulunmaktadır. Aaker (1991) çalışmasında dört ana marka değeri bileşeni tanımlamıştır. Bunlar; marka sadakati, algılanan kalite, marka birlikleri (turizm ve otelcilikte marka imajı olarak adlandırılır) ve marka farkındalığı olarak sıralanmaktadır. Keller (1993: 8); marka değerini "marka bilgisinin markanın pazarlanmasına tüketici tepkisi üzerindeki farklı etkisi" olarak tanımlamakta ve kavramı marka farkındalığı ile marka imajı olarak iki boyutta değerlendirmektedir. Bu iki çalışma arasındaki temel fark marka sadakatinde görülmektedir. Keller (1993) marka sadakatini müşteri temelli marka denkliğinin bir sonucu olarak görürken, Aaker'a (1991) göre ise marka sadakati, marka denkliğinin bir boyutu olarak kabul edilmektedir (Huang ve Cai, 2015). Ek olarak, Aaker'ın (1991) ve Keller'in (1993) önerilerine dayanarak, Yoo ve Donthu (2001)'da marka sadakati, algılanan kalite ve tek bir boyutta bir araya getirdiği marka farkındalığı ve imajını içeren üç boyutlu bir marka denkliği modeli geliştirmiştir.

Müşteri temelli marka denkliği kavramı ile ilgili literatürde hala oldukça farklı tanımlarının olduğu görülmekle beraber birçok yazar, marka değerinin Aaker (1991) tarafından önerilen dört algısal boyuttan, yani marka farkındalığı, marka imajı, algılanan kalite ve bir ilişkisel değişken olan marka sadakatinden oluştuğu konusunda hemfikir görünmektedir (Huang ve Chai, 2015; Seric vd., 2018: 1624).

Araştırmanın asıl konusunu oluşturan otel marka denkliği kavramını çeşitli şekillerde tarif etmek mümkündür. Prasad ve Dev (2000: 23-24), otel marka denkliğinin "bir müşterinin rezervasyon yapmasını etkileyen olumlu veya olumsuz tutum ve algılamalar" olarak değerlendirildiğini belirtmiştir. Otel marka denkliği "tüketicilerin bir otel markasıyla ilgili değer ve davranışlarını ayrıca markanın sonraki finansal performansı üzerindeki etkilerini” temsil etmektedir (Bailey ve Ball, 2006: 34).

\section{Marka Farkındalı̆̆ı}

Aaker (1991: 91) marka farkındalığını "bir müşterinin bir markanın belirli bir ürün kategorisinin üyesi olduğunu tanıma veya hatırlama yeteneği" olarak tanımlamakta ve insanların marka ile hatıraları arasında bağ kurabilmesi için bu markanın varlığından haberdar olmaları gerektiğini 
vurgulamaktadır. Keller (1993), marka farkındalı̆̆ını, müşterinin markayı hatırlama, tanımlama ve marka bileşenlerini belirli anılarla ilişkilendirebilme yeteneği olarak görmektedir.

Turizm bakış açısıyla marka farkındalığı, bir markanın turistin zihninde bulunan cazibesinin bir yansıması şeklinde tanımlanmaktadır. Bir markanın konaklama ve turizm üzerindeki etkisinin ana bileşeni olarak kabul edilmekte ve turistlerin memnuniyetini etkilediği söylenmektedir (Yuan ve Jang, 2008).

\section{Algılanan Kalite}

Zeithaml (1988) algılanan kaliteyi, müşterinin bir mal veya hizmetin genel mükemmelliği ve üstünlüğü hakkındaki kararı olarak tanımlamaktadır. Özellikle turizm tüketim deneyiminde algılanan kalite, turistin objektif veya gerçek kalite yerine algıladığı kaliteye yani sübjektif tahminine dayanmaktadır (Namkung ve Jang, 2013). Buna göre, algılanan kalite seviyesinin, gerçek hayatta birden fazla seçenekle karşılaşıldığında müşteri tüketim davranışını da etkilediği söylenmektedir (Lehmann ve Srinivasan, 2014).

Zeithaml (1988) algılanan marka değerinin hem dişsal hem de içsel nitelikler içerdiğini öne sürmüştür. İçsel nitelikler ürünün fiziksel görünümüyle ilgilidir. Bunlar şekil, görünüm, tat ve renk gibi özellikleri içerdiğinden kolayca gözlemlenebilmektedir. Dışsal nitelikler ise fiziksel olmamakla birlikte fiyat, marka adı, kalite güvencesi gibi hususları içermektedir (Nassar, 2017).

Algılanan hizmet kalitesi, ziyaretçinin memnuniyet düzeyi üzerinde önemli bir olumlu etkiye sahiptir. Mal veya hizmetin performansı müşterilerin beklentilerini karşılıyorsa memnuniyet gerçekleşmektedir. Müşterinin bir marka, mal veya hizmetten duyduğu memnuniyet, o markanın geniş çaplı değerlendirmesine işaret etmektedir (Sijoria vd., 2018).

\section{Marka Sadakati}

Aaker (1991) marka sadakatini "bir müşterinin bir markaya olan bağlılığı" olarak tanımlamakta ve Olivier (1997) ise, marka sadakatinin müşterilerin belirli markaları tercih etme eğilimi olduğunu ileri sürmektedir.

Turizm ürünlerinde veya destinasyonlarda oluşan marka sadakati genellikle turistlerin memnuniyetini ve diğer potansiyel turistlere tavsiyelerde bulunma istekliliğini açıklamak için kullanılmaktadır (Lee vd., 2011).

\section{Marka İmajı}

Aaker (1991) marka imajını "hafızada marka ile bağlantılı olan her şey" olarak tanımlamıştır. Marka imajı, marka ile ilgili tüm düşünceleri içermektedir (Kotler ve Keller, 2006). Turizm araştırmalarına bakıldığında, turistlerin destinasyon imajını olumlu değerlendirdiklerinde daha fazla memnuniyet duydukları belirtilmektedir (Chi ve Qu, 2008). Bu nedenle, bir ziyaretçinin marka imajı algısı, turizm ürünü veya destinasyon için ne kadar olumlu olursa, yüksek memnuniyetin devam etmesi o kadar olası görülmektedir (Liu ve Fang, 2018).

\section{Müşteri Temelli Marka Denkliği, Müş̧teri Memnuniyeti ve Güven}

Van Raaij vd. (2013), müşteri memnuniyetini, genel olarak insanların mutluluğu ve pazarlama faaliyetlerinin ana amacı için kilit rol oynayan son derece önemli bir davranışsal olgu olarak 
görmektedir (San Martin vd., 2019). Müşteri memnuniyetini güvence altına almak, hizmetlerin en yaygın ölçme ve değerlendirme biçimlerinden biri olduğu (Radojevic vd., 2015) ve itibar veya kârlılık gibi faktörlerle doğrudan bağlantılı kabul edildiği (González-Mansilla vd., 2019) için otel işletmelerinde yönetim ekiplerinin temel amaçlarından birisi olarak kabul edilmektedir.

Bazı çalışmalar turizm sektöründe marka farkındalığı ile müşteri memnuniyeti arasında dolaylı bir ilişki olduğunu göstermektedir. Örneğin, Yuan ve Jang (2008), marka farkındalığının turist memnuniyeti ile bağlantılı olabileceğini anlatmaktadır. Yapılan çalışmalar marka farkındalığının sadakat ve marka imajı yoluyla turist memnuniyetini etkilediğini göstermektedir. Yani, turizm ürününe yönelik gelişen marka farkındalığı, marka sadakatini ve marka imajını teşvik etmek için değerli bir katalizör görevi görmekte ve bunun da genel memnuniyeti arttırdığı söylenmektedir (Liu ve Fang, 2018). Bazı araştırmacılar ise marka denkliği boyutlarından algılanan kalitenin, memnuniyet düzeyi üzerinde etki sahibi olduğunu söylemektedir (González vd., 2007; Sijoria vd., 2018). Bunun yanında marka imajının müşteri memnuniyetinin önemli bir belirleyicisi olduğunu söyleyen çalışmalarda marka imajı ve müşteri memnuniyeti arasında pozitif bir ilişki olduğunu öne sürülmektedir (Chang ve Tu, 2005; Martenson, 2007). Öte yandan, bazı araştırmalar marka değeri ve müşteri memnuniyeti arasındaki ilişkiyi turizm sektörü ve özellikle otel işletmeleri bağlamında analiz etmiştir. Bihamta vd. (2017), hizmet kalitesi ve marka değerinin otel restoran memnuniyeti ile uluslararası ve yerel turistler arasında marka sadakati üzerindeki etkisini ele almışlardır. Aynı şekilde Uslu ve Karabulut (2019), Cittaslow Köyceğiz'deki slow food restoranların algılanan hizmet kalitesi ile marka sadakati, marka güveni ve marka imajı arasındaki ilişkileri incelemişlerdir. Nam vd. (2011), otel ve restoran endüstrisinde müşteri memnuniyetinin müşteri temelli marka denkliği ve marka sadakati arasındaki ilişkiye aracılık eden etkilerini araştırmıştır. Bunların dışında, Nassar (2017), yapısal eşitlik modelleme yöntemini kullanarak, marka denkliğinin Mısır otel endüstrisindeki müşteri memnuniyeti üzerindeki etkisini incelemiştir. Tüm bu teorik altyapıya dayanarak, aşağıda yer alan araştırma hipotezi kurulmuştur.

H1: Otel marka denkliğinin müşteri memnuniyeti üzerinde pozitif etkisi vardır.

Güçlü marka değeri olan bir hizmet, gelecekteki memnuniyet vaadinin yanı sıra, müşterinin göremedikleri bir ürünü satın alma konusundaki güvenini de arttırmaktadır (Berry, 2000). Güven, risk karşısında başka bir tarafa güvenme isteğidir ve bu istek, karşı tarafın geçmişteki deneyime dayalı anlayışından kaynaklanmaktadır (Lau ve Lee, 1999).

Kimpakorn ve Tocquer (2010), güvenin, otel marka denkliği çerçevesinde marka ilişkilerinin en önemli bağımsız değişkenlerinden biri olduğunun altını çizmektedir. Kim vd., (2008) çalışmalarında marka değerinin öncülü olarak hem güven hem de bağlılık değişkenini incelemiş ve kavram üzerindeki dolaylı etkilerini araştırmıştır. Benzer şekilde Liao (2015)'da güven ile marka değeri arasındaki ilişkiyi doğrulamış, rekabetçi bir pazarda satıcıya güvenmeyen müşterilerden marka sadakati oluşması olasılığının düşük olduğunu vurgulamıştır. Önceki çalışmalar güvenin öncül etkisine odaklanmış olsa da marka farkındalığı (Yoon, 2002), marka imajı (Jevons ve Gabbot, 2000; Yoon, 2002) gibi diğer marka denkliği boyutlarının da güven unsuru olduğu araştırmacılar tarafından belirtilmiştir. Bir başka çalışmada da müşteri temelli marka denkliğinin özellikle hizmetler göz önüne alındığında önemli bir güven unsuru olduğu ve müşterinin hizmete ilişkin risk algısını azalttığı ifade edilmiştir (Kim vd., 2008). Diğer yandan Altınöz (2013) yaptığı araştırmada marka denkliğinin güven ile pozitif ilişkisi olduğunu tespit etmiş̧tir. Bu doğrultuda müşteri temelli marka değeri ile güven arasında bir ilişkinin olduğu varsayımından hareketle araştırmanın diğer hipotezi oluşturulmuştur.

$\mathbf{H}_{2}$ : Otel marka denkliğinin güven üzerinde pozitif etkisi vardır. 
Güven kazanmadan önce müşterileri memnun etmek oldukça zor görünmektedir. Bu bağlamda güvenin müşteri memnuniyetini de etkilediği düşünülmektedir (Erciş vd., 2012). Erciş vd., (2012) çalışmalarının sonucunda memnuniyet ve güven arasında pozitif bir ilişki tespit etmişlerdir. Yapılan literatür taraması sonucunda bazı araştırmacıların müşteri memnuniyeti ile güven arasındaki ilişkiyi vurguladığı görülmüştür (Pizzutti ve Fernandes, 2010; Ribbink vd., 2004; Seric vd.,2018). Altınöz (2013) beş yıldızlı otel işletmelerinde gerçekleştirdiği araştırmada müşteri memnuniyeti ile güven arasında anlamlı bir ilişkinin olduğu sonucuna ulaşmıştır. Bu bağlamda $\mathrm{H}_{3}$ hipotezi oluşturulmuştur.

$\mathbf{H}_{3}$ : Güvenin müşteri memnuniyeti üzerinde pozitif etkisi vardır.

Yapılan literatür taraması sonucu Morgan ve Hunt (1994)'ın önerdiği modelde, güvenin genel memnuniyet ile marka bağlılığı arasında tam bir aracı rol oynadığı belirtilmektedir. DelgadoBallester ve Munuera-Alema'n (2005)'ın elde ettiği sonuçlar ise güvenin, Morgan ve Hunt'ın (1994) modelinde olduğu gibi tam bir aracı rolü olmasa da marka denkliğinin daha iyi açılanmasına katkıda bulunduğunu söylemektedir. Fatma vd., (2015) kurumsal sosyal sorumluluk ve marka denkliğini araştırdıkları çalışmalarında değişkenler arasında güvenin aracılık rolünün anlamlı olduğunu tespit etmişlerdir. Otel işletmeleri bağlamında marka denkliği ile marka sadakati arasında güvenin aracılık rolünün araştırıldığı diğer bir çalışmada aracı etkinin anlamlı olduğu sonucuna ulaşılmıştır (Altınöz, 2013). Bunun sonucunda oluşturulan $\mathrm{H}_{4}$ hipotezi şu şekildedir.

H4: Otel marka denkliğinin müşteri memnuniyeti üzerindeki etkisinde güvenin aracllık rolü vardir.

\section{YÖNTEM}

$\mathrm{Bu}$ araştırmanın amac1, Fethiye'ye gelen yabancı turistlerin konaklama işletmelerinin marka denkliğinin memnuniyetlerine ve güvene etkilerini belirlemek aynı zamanda otel marka denkliği ile memnuniyet arasındaki ilişkide güvenin aracı etkisini olup olmadığını incelemektir. Bu araştırma, alan yazına konunun özgünlüğü ve değişkenlerin arasındaki aracı ilişkileri açıklaması ve turistlerin davranışlarının daha iyi anlaşılabilmesi açısından önemlidir.

$\mathrm{Bu}$ araştırmada, marka denkliği boyutlarının (marka farkındalığı/bilinirliği, marka çağrışımı/imajı, algılanan kalite ve sadakat) turistlerin memnuniyet düzeylerine ve güvene etkilerini ve güvenin bu değişkenler arası ilişkide aracı rolünün tespit edebilmek için nicel bir araştırma yöntemi olan anket uygulanmıştır.

Araştırmada kullanılan anket, sosyo-demografik özellikleri tespit eden sorulardan ve 6 farklı ölçekten oluşmaktadır. Bunlardan otel marka denkliğinin alt boyutları olan marka farkındalığı ölçeğine ait 2 ifade, marka çağrışımı ölçeğine ait 2 ifade, algılanan kalite ölçeğine ait 4 ifade ve sadakat ölçeğine ait 3 ifade González-Mansilla vd., (2019) tarafından oluşturulan anketlerden uyarlanmıştır. Ayrıca ilişki kalitesinin alt boyutları olan müşteri memnuniyeti ölçeğine ait 4 ifade ve güven ölçeğine ait 5 ifade ise Woo ve Cha (2002) tarafından oluşturulan güvenilirliği ve geçerliliği sağlanmış çalışmalardan alınmış ve ankete uyarlanmıştır. Turizm işletmeciliği ve pazarlama alanında uzman 2 akademisyen tarafından anket soruları incelenmiş ve ana dili İngilizce olan bir uzman tarafından ankette yer alan ifadelerin kontrolü sağlanmıştır.

Araştırma, 2019 yılının 01 Haziran ve 31 Ağustos tarihleri arasında kolayda örnekleme yöntemi ile yazarlardan birisi tarafından yüz yüze görüşülerek gerçekleştirilmiştir. Konaklama işletmelerinden ayrılmak üzere olan yabancı turistlere anketler gerçekleştirilmeden önce araştırmanın amacından bahsedilmiş ve gönüllü olarak katılmak isteyenlerden 325 anket elde 
edilmiştir. İçerisinde boş bırakılan ve hatalı olan 23 anket çıkarılmış ve geriye kalan 302 adet anket üzerinden araştırma gerçekleştirilmiştir. Fethiye Turizm Danışma Bürosu'nun 2019 yılı verilerine göre Fethiye'ye gelen yabancı turist sayısı 680 bin kişidir. Bryman ve Cramer (2001) ölçekte kullanılan ifade sayısının beş ya da onla çarpılmasıyla yeterli örneklem büyüklügünün elde edileceğini ifade etmektedir. Buradan hareketle anket ölçeğindeki ifade sayılarının toplamda 20 olduğu araştırmada, en az $20^{*} 10=200$ anketin olması gerekmekte olup elde edilen 302 anketin evreni temsil etmede yeterli olduğu ifade edilebilir (Bryman ve Cramer, 2001). Elde edilen verilere SPSS 22.00' de frekans, faktör analizi yapılmış ve Kısmı en küçük kareler olan Smart PLS 2 paket programı ile araştırma modeli test edilmiştir. Aracı etkinin test edilmesinde ise Sobel testinden yararlanılmıştır.

\section{Araştırmanın Modeli}

Model, "ideal" bir ortamın temsilcisi olup sadece "önemli" olduğu düşünülen değişkenleri içine alacak şekilde gerçek durumun özetlenmiş halidir (Karasar, 2005). Bu araştırmada otel marka denkliğinin alt boyutları olan marka farkındalığı, marka çağrışımı, algılanan kalite ve sadakat ile müşteri memnuniyeti ve güven değişkenleri araştırmanın amaçları doğrultusunda kullanılacak modele uyarlanmıştır.

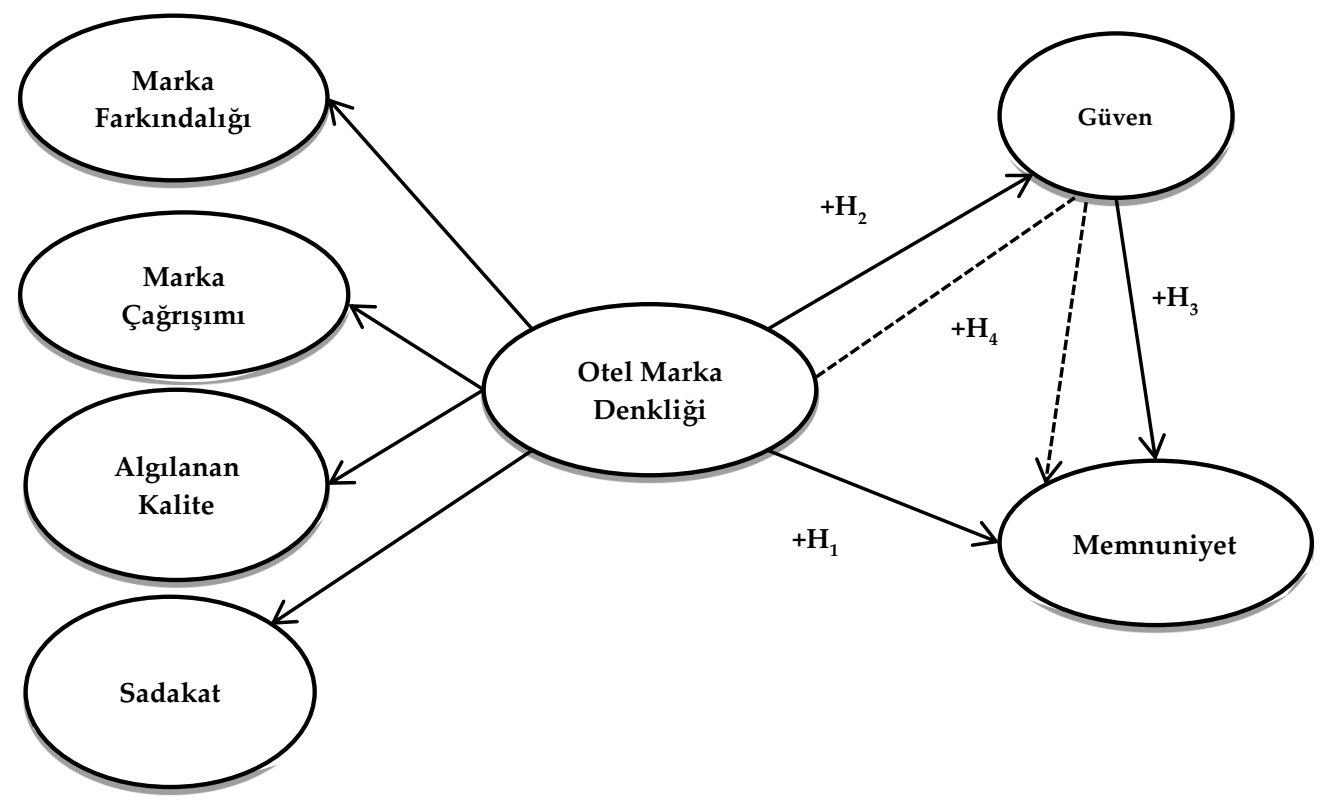

Şekil 1. Araştırma Modeli

\section{ARAŞTIRMANIN BULGULARI}

Tablo 1'e göre araştırmaya katılan yabancı turistlerin sosyo-demografik özelliklerine göre \%55.3 (167)'i kadınlardan ve \%44.7 (135)'isi erkeklerden oluşmaktadır. Otel işletmelerine gelen yabancı turistlerin yaş ortalaması ise 44.54 gibi orta yaş grubunda olduğu tespit edilmiştir. Turistlerin medeni durumlarına bakıldığında ise \%51.7 (156)'isi bekar ve \%48.3 (146)'i evli kişilerdir. Gelen yabancı turistlerin büyük bir çoğunluğu (\%89.1) İngiliz turistlerden oluşmaktadır. Öğrenim durumlarına bakıldığında ise daha çok (\%34.1) üniversite-lisans mezunu ve (\%31.1) lise mezunu turistlerden oluşmaktadır. Gelen turistlerin daha çok (\%72.8) 7 gün ve üzeri konaklamaya sahip oldukları ve (\%52.7) sürekli müşterilerden oluştuğu anlaşılmaktadır. 
Tablo 1. Yabancı Turistlerin Sosyo-Demografik Özellikleri

\begin{tabular}{lcclccc}
\hline Cinsiyet & f & $\mathbf{\%}$ & Medeni Durum & f & \% \\
\hline Erkek & 135 & 44.7 & Evli & 146 & 48.3 \\
Kadın & 167 & 55.3 & Bekâr & 156 & 51.7 \\
\hline Milliyeti & $\mathbf{f}$ & $\mathbf{\%}$ & Öğrenim Durumu & $\mathbf{f}$ & $\mathbf{\%}$ \\
\hline İngiltere & 269 & 89.1 & İlkokul & 7 & 2.3 \\
Hollanda & 7 & 2.3 & Ortaokul & 52 & 17.2 \\
İskoçya & 18 & 6.0 & Lise & 94 & 31.1 \\
İrlanda & 2 & 0.7 & Üniversite-Lisans & 103 & 34.1 \\
Rusya & 6 & 2.0 & Lisansüstü & 14 & 4.6 \\
\hline Konaklama Süresi & $\mathbf{f}$ & $\mathbf{\%}$ & Otele Geliş Sayısı & $\mathbf{f}$ & $\mathbf{\%}$ \\
\hline 1-7 gün arası & 82 & 27.2 & İlk kez gelen müşteri & 143 & 47.4 \\
7 gün üzeri & 220 & 72.8 & Repat müşteri & 159 & 52.6 \\
\hline Toplam & $\mathbf{3 0 2}$ & $\mathbf{1 0 0}$ & Toplam & $\mathbf{3 0 2}$ & $\mathbf{1 0 0}$ \\
\hline
\end{tabular}

\section{AFA Analizleri ve Ölçüm Modeli (DFA)}

Araştırmanın ölçüm modelinden önce modele girecek tüm değişkenlere yönelik açıklayıcı faktör analizleri (AFA) yapılmıştır. Otel marka denkliği ölçeğine yapılan AFA sonucunda; otel marka denkliği ölçeği KMO değeri 0.875 , Bartlett testi sonucu ki kare $(\chi 2)$ değeri 4226.781, müşteri memnuniyeti ölçeğinin ise KMO değeri 0.850, Bartlett testi sonucu ki kare $(\chi 2)$ değeri 1016.300 ve son olarak müşteri güveni ölçeğine yönelik KMO değeri 0.864, Bartlett testi sonucu ki kare $(\chi 2)$ değeri1496.031, tüm değişkenlere ait faktör yükleri 0.50 değerinden oldukça yüksek ve anlamlllık düzeyi $\mathrm{p}=0.000$ olarak bulunmuştur. Otel marka denkliği ölçeğine yönelik yapılan AFA sonucunda toplam varyansın \% 91.504'ünü açıklayan dört boyutlu bir yapı ortaya çıkmıştır. Bu boyutlar marka farkındalığı, marka çağrışımı, algılanan kalite ve sadakat şeklinde olup faktör yükleri 0.897 ile 0.764 arasında bulunmuştur. Müşteri memnuniyetine ilişkin ifadeler, toplam varyansın \% 83.021'ini açıklayan tek bir boyut altında toplanmıştır. Bu değişkenleri oluşturan ifadelerin faktör yükleri ise 0.937 ile 0.883 arasında tespit edilmiştir. Müşteri güvenine ilişkin ifadelerin toplam varyansın \% 81.883'ünü açıklayan tek bir boyut altında toplanmış olup ve faktör yükleri 0.923 ile 0.875 arasında çıkmıştır.

Tüm bu yapılan AFA sonuçları neticesinde araştırmanın modeline uygun olduğunu göstermektedir. Yapısal eşitlik modeli yapılabilmesi için öncelikle ölçüm modeline bakılması ve uygunluğunun değerlendirilmesi gerekmektedir. Bu bakımdan öncelikle içsel tutarlılığının uygunluğu için Cronbach's alpha katsayısına ve bileşik güvenilirlik değerlerine bakılması gerekir (Fornell ve Larcker, 1981). Cronbach's alpha katsayısının 0.70'den ve bileşik güvenilirlik değerlerinin 0.8'den büyük değerlere sahip olması gerekmektedir (Werts vd., 1974; Byrne, 2010; Hair vd., 2014). Araştırmada yer alan tüm boyutlara ait Cronbach's alpha katsayısının ve bileşik güvenilirlik değerlerinin yüksek derecede güvenilirliğe sahip olduğu görülmektedir ve bu durum içsel geçerliliğinin sağlandığı anlamına gelmektedir.

Ölçüm modelinde içsel geçerliliğin ardından yakınsak ve ayırt edici geçerliliklerinin uygunluğuna bakılmaktadır. Yakınsak geçerliliğini için standardize edilmiş faktör yükleri, $t$ değerleri ve $t$-değerlerinin anlamlılığ bakılmaktadır. Standardize edilmiş faktör yükleri, $t$-değerleri, AVE ile bileşik güvenilirlik değerleri Tablo 2'de sunulmaktadır. Buna göre faktör yüklerinin $0.7^{\prime}$ in ve $t$-değerlerinin ise 2.56 'nın çok üzerinde olduğu görülmektedir (Schumacker ve Lomax, 2004). Aynı zamanda tdeğerleri $\alpha=0.001$ düzeyinde anlamlı ve boyutların tamamı 0.50 ' eşiğinin çok üstünde olan AVE değerlerine sahip olduğu için yakınsak geçerliliğinin sağlandığı ifade edilebilir. Ölçüm modeline giren gizil değişken sayısı altı ve 20 gözlenen değişkenden oluşmaktadır. Otel marka denkliği ikinci düzey gizil yapı olarak 4 gizil değişkenin (marka farkındalığı, marka çağrışımı, algılanan kalite, sadakat) birleştirilmesi sonucunda bir gizil yapı haline getirilmiştir. 
Tablo 2. Ölçüm Modeli Sonuçları ve Güvenilirlik Katsayıları

\begin{tabular}{|c|c|c|c|c|c|}
\hline Boyutlar ve İfadeler & $\begin{array}{l}\text { Faktör } \\
\text { Yükleri }\end{array}$ & $t$-değeri & $\begin{array}{c}\text { Bileşik } \\
\text { Güvenilirlik }\end{array}$ & $\begin{array}{c}\text { Açıllanan } \\
\text { Ortalama } \\
\text { Varyans } \\
\text { (AVE) }\end{array}$ & $\begin{array}{c}\text { Cronbach's } \\
\text { Alpha } \\
\text { Katsayısı }\end{array}$ \\
\hline \multicolumn{6}{|l|}{ Birinci Düzey } \\
\hline Marka Farkındalığı & & & 0.982 & 0.964 & 0.963 \\
\hline $\begin{array}{l}\text { Otelin markasını, diğer rakiplerin markalarından } \\
\text { kolayca ayırt edebilirim. }\end{array}$ & 0.748 & 19.663 & & & \\
\hline Otelin sembolünü ve logosunu tanıyabilirim. & 0.718 & 18.108 & & & \\
\hline Marka Çağrışımı & & & 0.995 & 0.991 & 0.991 \\
\hline $\begin{array}{l}\text { Otel markasını neyin karakterize ettiğini kolayca } \\
\text { tahmin edebilirim. }\end{array}$ & 0.821 & 37.495 & & & \\
\hline $\begin{array}{l}\text { Otelin marka değerlerini, kendiliğimden } \\
\text { hatırlayabilirim. }\end{array}$ & 0.818 & 36.861 & & & \\
\hline Alg1lanan Kalite & & & 0.958 & 0.852 & 0.942 \\
\hline Otel, iyi bir eğlence demektir. & 0.857 & 49.356 & & & \\
\hline Otel, mükemmel bir gastronomi demektir. & 0.854 & 50.398 & & & \\
\hline Otel, olağanüstü bir konum (yer) demektir. & 0.815 & 32.331 & & & \\
\hline Otel, mükemmel bir hizmet demektir. & 0.858 & 50.669 & & & \\
\hline Sadakat & & & 0.960 & 0.890 & 0.938 \\
\hline Kendimi bu otelin hayranı olarak görüyorum. & 0.803 & 35.441 & & & \\
\hline Bir otel seçerken ilk tercihim bu otel olacak. & 0.782 & 31.804 & & & \\
\hline $\begin{array}{l}\text { Eğer bir otele gitme şansım olursa, başka bir otel } \\
\text { zincirini seçmeyeceğim. }\end{array}$ & 0.752 & 23.745 & & & \\
\hline Memnuniyet & & & 0.948 & 0.860 & 0.918 \\
\hline $\begin{array}{l}\text { Otelin uygun bir hizmet sağlayıcı olduğunu } \\
\text { düşünüyorum. }\end{array}$ & 0.882 & 55.667 & & & \\
\hline Bir otel çalışanından memnunum. & 0.936 & 111.012 & & & \\
\hline Tüm otel çalışanlarından memnunum. & 0.928 & 55.512 & & & \\
\hline Otelin tüm ürünlerinden memnunum. & 0.897 & 49.120 & & & \\
\hline Güven & & & 0.958 & 0.819 & 0.945 \\
\hline Otel çalışanları sözlerinde durmaktadır. & 0.875 & 48.270 & & & \\
\hline Otel çalışanları samimidir. & 0.911 & 51.261 & & & \\
\hline Otel çalışanları güvenilirdir. & 0.916 & 59.409 & & & \\
\hline Otel çalışanları dürüsttür. & 0.923 & 93.409 & & & \\
\hline $\begin{array}{l}\text { Otel çalışanları müşteri çıkarlarını ilk sıraya } \\
\text { koymaktadır. }\end{array}$ & 0.897 & 64.864 & & & \\
\hline \multicolumn{6}{|l|}{ İkinci düzey } \\
\hline Otel Marka Denkliği & & & 0.952 & 0.646 & 0.945 \\
\hline Marka Farkındalığı & 0.771 & 25.811 & & & \\
\hline Marka Çağrışımı & 0.844 & 55.977 & & & \\
\hline Algılanan Kalite & 0.909 & 93.640 & & & \\
\hline Sadakat & 0.807 & 35.125 & & & \\
\hline
\end{tabular}

Not: Tüm faktör yüklerinin anlamlllk seviyesi p<0.001 ve 2000 örneklem üzerinden bootsrapping yapılmıştır.

Korelasyon değerleri ile açıklanan ortalama varyans (AVE) katsayısı karekök değerlerinin karşılaştırılması yoluyla ise ayırt edici geçerlilik kriterine bakılmaktadır. Tablo 3'de korelasyon değerlerinin köşegen değerlerinden daha düşük olduğu görülmüş ve ayırt edici geçerliliğin sağlandığı tespit edilmiştir (Fornell ve Larcker, 1981).

Tablo 3. Aritmetik Ortalama, Standart Sapma, Ayırt Edici Geçerlilik ve Korelasyon Değerleri

\begin{tabular}{lccccc}
\hline & A.O. & S.S. & Otel Marka Denkliği & Memnuniyet & Güven \\
\hline Otel Marka Denkliği & 3.86 & .813 & $.80^{\mathrm{a}}$ & & \\
Memnuniyet & 4.01 & .899 & $.79^{*}$ &. $\mathbf{9 3}^{\mathrm{a}}$ & $.79^{*}$ \\
Güven & 4.03 & .875 & $.73^{*}$ &. $\mathbf{9 1}^{\mathrm{a}}$ \\
\hline Not: ${ }^{*} \mathrm{p}<0,001$, a=Köşegen üzerindeki koyu olarak belirtilmiş değerler, AVE değerlerinin kareköküdür.
\end{tabular}


Yapısal modele giren ve çok değişkenin yer aldığ 1 analizlerde korelasyon değerlerinin $\pm 0,3$ ile $\pm 0,9$ değerleri arasında olması istenmektedir (Raykov ve Marcoulides, 2006). Tablo 2' de buna göre korelasyon değerlerinin her birisinin bu değerlerin arasında olduğu ve değişkenler arası ilişkilerin incelenebileceğine işaret etmektedir. Araştırmaya katılan yabancı turistlerin verdikleri cevapların aritmetik ortalamalarına bakıldığında en yüksek aritmetik ortalamaya ( $\bar{x}=4.03)$ sahip değişkenin "güven" boyutu olduğu, bunun dışında "müşteri memnuniyeti" boyutunun da $(\bar{x}=4.01)$ ikinci en yüksek aritmetik ortalamaya sahip olduğu görülmektedir. En düşük aritmetik ortalamanın ise ( $\mathrm{x}=3.86)$ "otel marka denkliği" faktörü olduğu belirlenmiştir.

\section{Yapısal Model ve Hipotezlerin Test Edilmesi}

Yapısal modelde ilk olarak otel marka denkliğinin müşteri memnuniyeti ve güvene etkisi ile güvenin memnuniyet davranışına etkisini incelenmiştir. PLS'de yapısal modelin uygunluğunu değerlendirilmesinde yapısal modelin uygun olup olmadığının değerlendirilmesinde öncelikli olarak R² değerleri ve yol katsayıları olmak üzere iki temel endeks vardır (Vinzi vd., 2010). Araştırmadaki güven değişkeninin $\mathrm{R}^{2}$ değeri 0.526 ve müşteri memnuniyeti değişkeninin $\mathrm{R}^{2}$ değeri ise 0.735 olarak bulunmuştur. Bulunan bu $\mathrm{R}^{2}$ değerleri, 0.10 olarak belirlenen eşik değerin çok üstünde yer almaktadır (Falk ve Miller, 1992). Yapısal modelde bulunan $\beta$ katsayıları (0.455, $0.725,0.469)$ ve $\mathrm{R}^{2}$ değerleri kurulan yapısal modelinin iyi uyuma sahip olduğunu göstermektedir.

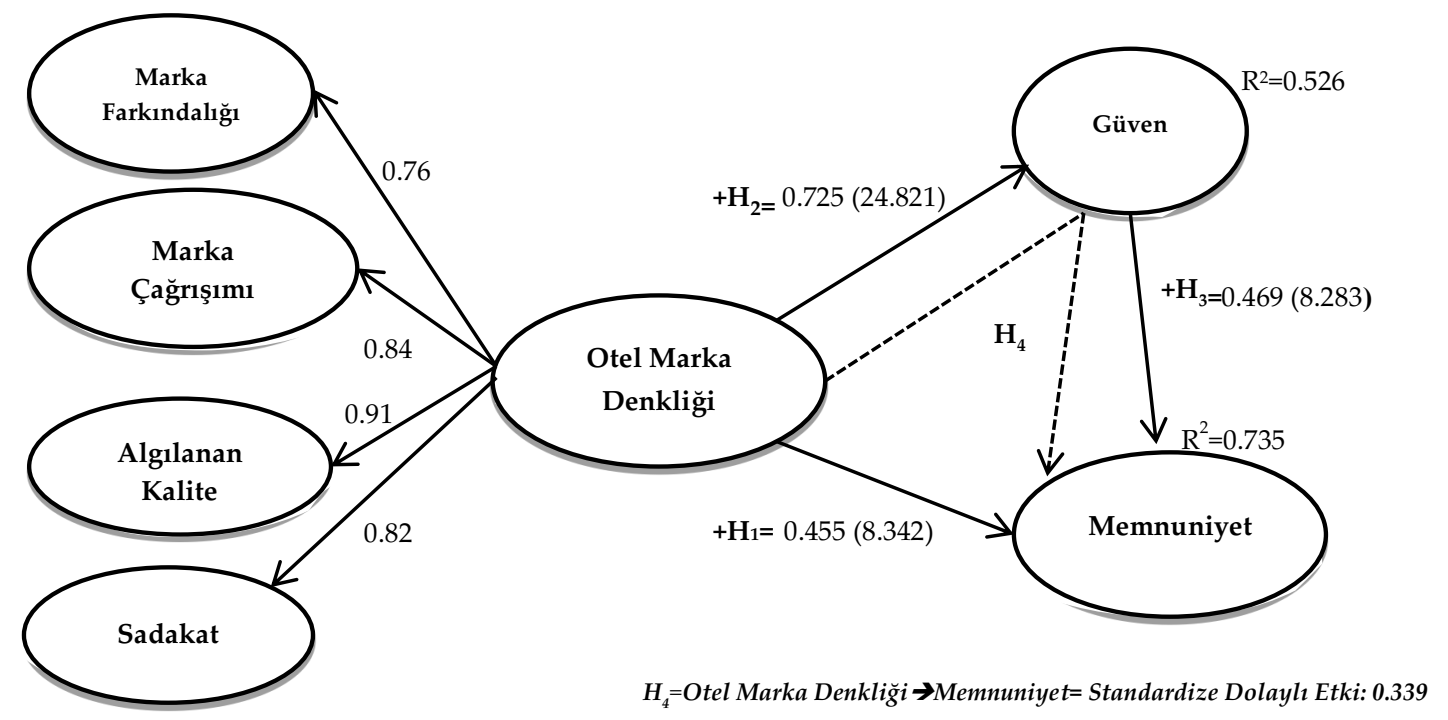

Şekil 2. Araştırma Modeli ve Sonuçları

Otel marka denkliğinin müşteri memnuniyeti $(\beta=0.455, t=8.342$, $\mathrm{p}<0.001)$ ve müşteri güveni $(\beta=0.725, t=24.281, p<0.001)$ üzerinde istatistiksel açıdan anlamlı ve pozitif etkilere sahip olduğu belirlenmiştir. Ayrıca müşteri güveninin memnuniyet üzerinde $(\beta=0.469, t=8.283, p<0.001)$ anlamlı ve pozitif etkileri olduğu saptanmıştır. Böylelikle kurulan $\mathrm{H}_{1}, \mathrm{H}_{2}, \mathrm{H}_{3}$ hipotezleri desteklenmiştir. 
Tablo 4. Hipotez Testi Sonuçları

\begin{tabular}{lccc}
\hline Hipotezler & Yol (Path) Katsayısı & $\boldsymbol{t}$-değeri & Sonuçlar \\
\hline Otel Marka Denkliği $\rightarrow$ Memnuniyet & 0.455 & $8.342^{\text {a }}$ & Desteklendi \\
Otel Marka Denkliği $\rightarrow$ Güven & 0.725 & $24.821^{\text {a }}$ & Desteklendi \\
Güven $\rightarrow$ Memnuniyet & 0.469 & $8.283^{\text {a }}$ & Desteklendi \\
Otel Marka Denkliği $\rightarrow$ Güven $\rightarrow$ Memnuniyet & & & Desteklendi \\
\hline Not: 2000 örnekleme kadar bootsrapping yapılmıştır. a $p<0.001$ & & \\
\hline
\end{tabular}

\section{Müşteri Güveninin Aracı (Mediator) Etkisi}

Otel marka denkliğinin müşteri memnuniyetine etkisinde müşteri güveninin aracı (mediator) etkisini tespit edebilmek amacıyla $\mathrm{H}_{4}$ hipotezi kurulmuştur. Aracı etkisini araştırmak için değişkenler arasındaki doğrudan, dolaylı ve toplam etkilerine bakılması gerekmektedir. Aracı etkilerin belirlenmesinde Baron ve Kenny (1986) yaklaşımıyla hareket edilmiştir. Bu durumda aracı etki ile ilgili dört adımın gerçekleşmesi gerekmektedir. İlk üç adım bağımsız değişken ve bağımlı değişken arasında, bağımsız değişken ve aracı (mediator) değişken arasında, aracı değişken ve bağımlı değişken arasında anlamlı ilişkilerin olmasıdır. Dördüncü şart ise bağımlı değişken, bağımsız değişken ve aracı değişken aynı anda analize tabi tutulduğunda, bağımlı değişken ve bağımsız değişken arasında anlamlı olmayan bir ilişki ortaya çıkarsa tam aracılık etkisinden bahsedilirken bağımlı değişken ile bağımsız değişken arasındaki ilişkinin azalması durumunda ise kısmi aracılık etkisinden söz edilebilmektedir (Prayag vd., 2013). İlişkide meydana gelen azalmanın anlamlı olup olmadığının değerlendirilmesi için Sobel testi gerçekleştirilir ve Sobel testinin anlamlı çıkması durumunda kısmi aracılık etkisinden bahsedilebilmektedir. Aynı zamanda Tablo 5'e göre otel marka denkliğinin müşteri memnuniyeti üzerindeki dolaylı etkisinin (0.339), toplam etkinin önemli bir bölümünü oluşturduğunu görülmekte ve bu durum aracı etkisinin olduğunun bir göstergesi olabilmektedir.

Tablo 5. İlişkilerin Doğrudan, Dolaylı ve Toplam Etkileri

\begin{tabular}{lccc}
\hline Yollar & Doğrudan etki & Dolaylı etki & Toplam etki \\
\hline Otel Marka Denkliği- $\rightarrow$ Güven & 0.725 & - & 0.725 \\
Otel Marka Denkliği $\rightarrow$ Memnuniyet & 0.455 & 0.339 & 0.794 \\
Güven $\rightarrow$ Memnuniyet & 0.469 & - & 0.469 \\
\hline
\end{tabular}

Sobel testinde kullanılması için gerekli olan standardize edilmemiş regresyon katsayıları ve standart hata değerlerini Smart PLS paket programında 2000 örneklem sayısı üzerinden bootstrapping yapılarak elde edilmiş ve ilgili değerlerin internet sitesi üzerinden (http://quantpsy.org/sobel/sobel.htm) hesaplama programına girilerek yapılmıştır. Elde edilen Sobel testi sonucuna göre, otel marka denkliği ile müşteri memnuniyeti arasındaki ilişkide müşteri güveninin aracılık ilişkisi bulunmuştur (Sobel's z-değeri=6.139, çift yönlü $p$ değeri=0.00; Aroian's z-değeri=6.122, çift yönlü $p$ değeri $=0.00$; Goodman's z-değeri= 6.157, çift yönlü $p$ değeri $=0.00$ ). Sobel testinin geçerli olabilmesi için anlamlılık $\mathrm{z}$-değeri=1.96'dan büyük ve $\mathrm{p}$ değerinin 0.05'den küçük olması gerekir (Sobel, 1982; Frazier vd., 2004). Bu sonuçlar doğrultusunda çalışmanın dördüncü ve son hipotezi olan güvenin, otel marka denkliği ve müşteri memnuniyeti arasındaki ilişkide kısmı aracılık rolünün var olduğu belirlenmiştir. Bu durumda Baron ve Kenny (1986) tarafından aracılık için belirtilen tüm adımlar karşılandığı için Tablo 6' da görüldüğü üzere elde edilen sonuçlar, $\mathrm{H}_{4}$ hipotezini kısmen desteklemektedir. Çünkü otel marka denkliği ile 
müşteri memnuniyeti arasındaki ilişki güven değişkenin aracı etkisi ile birlikte önemli ölçüde azalmaktadır.

Tablo 6. Aracı Etkinin Test Sonuçları

\begin{tabular}{|c|c|c|c|}
\hline Mediating (Aracı) Etki Adımları & Beta $(\beta)$ Katsayısı & $t$-değeri & $p$ \\
\hline $\begin{array}{l}\text { 1.adım-Bă̆ımsız değişsen-Bağımlı değişken } \\
\text { Otel Marka Denkliği-Memnuniyet }\end{array}$ & 0.794 & 33.897 & $p<0.001$ \\
\hline $\begin{array}{l}\text { 2.adım-Bağımsız değişken-Aracı değişken } \\
\text { Otel Marka Denkliği-Güven }\end{array}$ & 0.725 & 24.821 & $p<0.001$ \\
\hline $\begin{array}{l}\text { 3.adım-Aracı değişken-Bă̆ımlı değiş̧ken } \\
\text { Güven-Memnuniyet }\end{array}$ & 0.469 & 8.283 & $p<0.001$ \\
\hline $\begin{array}{l}\text { 4.adım Bă̆ımsız değişken-Aracı değişken-Bağımlı değişken } \\
\text { Otel Marka Denkliği-Güven-Memnuniyet }\end{array}$ & 0.455 & 8.342 & $p<0.001$ \\
\hline
\end{tabular}

\section{TARTIŞMA, SONUÇ ve ÖNERİLER}

Küresel pazarlarda meydana gelen hızlı değişime ve artan rekabet ortamına bağlı olarak kırılgan bir yapıya sahip olan turizm sektörünün içerisinde bulunan yoğun rekabet ortamı düşünüldüğünde, sadık müşteriler oluşturmanın önemi büyüktür. Nitekim son dönemlerde sadık müşteriler oluşturmada marka denkliği kavramı önemini her geçen gün artıran bir kavramdır.

Araştırmadan elde edilen otel marka denkliğinin müşteri güvenini olumlu yönde etkilediği sonucu, alan yazındaki diğer çalışmaların sonuçlarıyla örtüşmektedir (Jevans ve Gabbot, 2000; Yoon, 2002; Kim vd., 2008; Altınöz, 2013). Araştırma bulgularına göre otellerin marka denkliği arttıkça, müşterilerin otellere yönelik güveni de artmaktadır ve otel marka denkliği aynı zamanda müşteri memnuniyeti ile de olumlu yönde ilişkilidir. Prasad ve Dev (2000), Nam vd., (2011), Nassar (2017), Yuan ve Jang (2008), Liu ve Fang (2018) ve Altınöz (2013)'ün çalışmalarından elde edilen bulgular da bu sonucu destekler nitelikte olup, ziyaretçilerin otele ilişkin marka denkliğini yüksek algılamalarının, otelden memnun olma düzeylerini de artırdığını ifade etmek mümkündür.

Araştırmada müşteri güveni ile müşteri memnuniyeti arasında da doğru yönlü bir ilişki tespit edilmiştir. Müşterinin otelde kendisini güvende hissetmesi de haliyle müşterinin otelden duyduğu memnuniyet düzeyinin artmasını sağlayacaktır. Bu sonuç da alan yazındaki birçok araştırmanın sonuçlarıyla benzerlik göstermektedir (Altınöz, 2013; Erciş vd., 2012). Araştırmanın en önemli bulgusu ise otel marka denkliğinin müşteri memnuniyetine etkisinde, güvenin kısmi aracılık etkisine sahip olduğudur. Bu bulgu alanyazındaki (Altınöz, 2013; Morgan ve Hunt, 1994; Delgado-Ballester ve Munuera-Alema'n, 2005) çalışmalar ile paralellik göstermektedir. Böylece otelin marka denkliği ile müşteri memnuniyeti arasındaki ilişkinin güven değişkeni üzerinden gerçekleştiği belirtilebilir.

Araştırma, otel işletmelerinin sadık müşteri kitlesi elde etme sürecinde, müşterilerine güven verebilme ve müşterilerini memnun edebilme amaçlarına ulaşabilmek için marka denkliği kavramını tüm boyutlarıyla birlikte önemsemeleri gerektiğini göstermektedir. Konaklama sektöründe hizmetlerin her şey dahil sisteme dönüştügü ve birçok markanın birbirine benzer algılandığı düşünüldüğünde marka denkliği kavramlarını arttırıcı faaliyetlerin sürdürülmesi, ilişki kalitesi alt boyutları olan güven ve memnuniyet seviyelerinin artmasına yardımcı 
olabilecektir. Turistlerin marka denkliği algılamalarını arttırarak farklılaşabilmek isteyen oteller, pazarlama iletişimi faaliyetlerinden (reklam, tanıtım, tutundurma vb.) yararlanabileceklerdir.

Araştırma, maliyet ve zaman kısıtları nedeniyle önemli kıyı turizm destinasyonu olan Muğla ilinin Fethiye ilçesinde gerçekleştirilmiştir. Elde edilen sonuçların genellenebilmesi için daha geniş örneklemlerle çalışma genişletilebilir. Ayrıca Fethiye destinasyonuna gelen yabancı turistler üzerinde gerçekleştirilen araştırma, yerli turistlere de uygulanıp elde edilecek bulgular kıyaslanabilir. Müşteri memnuniyetine olan etkileri göz önüne alındığında, otellere yönelik marka denkliği ve güven değişkenlerinin artmasını sağlayacak unsurların neler olabileceği konusunda da çalışmalar yapılabilir.

\section{KAYNAKÇA}

Aaker, D. A. (1991). Managing Brand Equity. New York, NY: Free Press.

Aaker, D. A. and Joachimsthaler, E. (2000). The brand relationship spectrum: The key to the brand architecture challenge. California Management Review, 42(4), 8-23.

Altınöz, Ö. (2013). Otel İşletmelerinde Müşteri Odaklı Marka Denkliğinin Müşteri Sadakatine Etkisi: Müşteri Memnuniyeti ve Güvenin Aracı Rolü. Yayınlanmamış doktora tezi, Gazi Üniversitesi, Ankara.

Bailey, R. and Ball, S. (2006). An exploration of the meaning of hotel brand equity. Service Industries Journal, 26(1), 15-38.

Baron, R.M. and Kenny, D.A. (1986). The moderator-mediator variable distinction in social psychological research: Conceptual, strategic and statistical considerations. Journal of Personality and Social Psychology, 51(6), 1173-1182.

Berry, L.L. (2000). Cultivating service Brand equity. Journal of the Academy of Marketing Science, 28(1), 128-137.

Bihamta, H., Jayashree, S., Rezaei, S., Okumus, F. and Rahimi, R. (2017). Dual pillars of hotel restaurant food quality satisfaction and brand loyalty. British Food Journal, 119(12), 2597-2609.

Bryman, A. and Cramer, D. (2001). Quantitative data analysis with SPSS Release 10 for Windows. London: Routledge.

Byrne, M. B. (2010). Structural Equation Modeling with AMOS (Second Edition), New Jersey, USA: Lawrence Erbaum Associates Publisher.

Chang, H., H., Hsu, C., H. and Chung, S. H. (2008). The antecedents and consequences of brand equity in service markets. Asia Pacific Management Review, 13 (3), 601-624.

Chang, C. H. and Tu C. Y. (2005). Exploring Store Image, Customer Satisfaction and Customer Loyalty Relationship: Evidence from Taiwanese Hypermarket Industry. Journal of American Academy of Business, 7(2), 197-202.

Chi, C. G. Q. and Qu, H. (2008). Examining the structural relationships of destination image, tourist satisfaction and destination loyalty: An integrated approach. Tourism Management, 29, 624636.

Delgado-Ballester, E. and Munuera-Alema'n, J. L. (2005). Does brand trust matter to brand equity?. Journal of Product \& Brand Management, 14(3), 187-196. 
Erciş, A., Ünal, S., Candan, F. B. and Yıldırım, H. (2012). The effect of brand satisfaction, trust and brand commitment on loyalty and repurchase intentions. Social and Behavioral Sciences, 58, 1395 1404.

Falk, R. F. and Miller, N. B. (1992). A primer for soft modelling. Akron, OH: University of Akron Press.

Fatma, M., Rahman, Z. and Khan Imran (2015). Building company reputation and brand equity through CSR: the mediating role of trust. International Journal of Bank Marketing, 33(6), 840-856.

Fethiye Turizm Danışma Bürosu (2019). Turizm İstatistikleri.

Fornell, C. and Larcker, D. F. (1981). Evaluating structural equation models with unobservable variables and measurement error. Journal of Marketing Research, 18(1), 39-50.

Forgacs, G. (2003). Brand asset equilibrium in hotel management. International Journal of Contemporary Hospitality Management, 15(6), 340-342.

Frazier, P.A., Tix, A.P. and Barron, K.E. (2004). Testing moderator and mediator effects in counseling psychology research. Journal of Counseling Psychology, 51(1), 115-134.

Gonzalez, M. E. A., Comesana, L. R. and Brea, J. A. F. (2007). Assessing tourist behavioral intentions through perceived service quality and customer satisfaction. Journal of Business Research, 60, 153-160.

González-Mansilla, O., Berenguer-Contríb, G. and Serra-Cantallops, A. (2019). The impact of value co-creation on hotel brand equity and customer satisfaction. Tourism Management, (75), 5165.

Guest, L. P. (1942). The genesis of brand awareness. Journal of Applied Psychology, 26, 800-808.

Hair, J., Black, W., Babin, B. and Anderson, R. (2014). Multivariate Data Analysis (7th Edition). Pearson New International Edition.

Horng, J. S., Liu, C. H., Chou, H. Y. and Tsai C. Y. (2012). Understanding the impact of culinary brand equity and destination familiarity on travel intentions. Tourism Management, 33, 815-824.

Hsu, C. H., Oh, H. and Assaf, A. G. (2011). A customer-based brand equity model for upscale hotels. Journal of Travel Research, 51(1), 81-93.

Huang, Z. J. and Cai, L. A. (2015). Modelling consumer-based brand equity for multinational hotel brands-When hosts become guests. Tourism Management, 46, 431-443.

Jevons, C. and Gabbott, M. (2000), Trust, brand equity and brand reality in internet business relationships: an interdisciplinary approach, Journal of Marketing Management, 16(6) ,619-34.

Karasar, N. (2005). Bilimsel Araştırma Yöntemi, Ankara: Nobel Yayıncilık.

Kayaman, R. and Arasli, H. (2007). Customer based brand equity: Evidence from the hotel industry. Managing Service Quality, 17(1), 92-109.

Keller, K. L. (1993). Conceptualizing, measuring, and managing customer-based brand equity. Journal of Marketing, 57(1): 1-22.

Keller, K. L. (2009). Building strong brands in a modern marketing communications environment. Journal of Marketing Communications, 15(2/3): 139-155.

Kim, H. B., Kim, W. G. and An, J. A. (2003). The effect of customer-based brand equity on firms' financial performance. Journal of Customer Marketing, 20(4), 335-351. 
Kim, H. and Kim, W. G. (2005). The relationship between brand equity and firms' performance in luxury hotels and restaurants. Tourism Management, 26(4), 549-560.

Kim, K. H., Kim, K. S., Kim, D. Y., Kim, J. H. and Kang, S. H. (2008). Brand equity in hospital marketing. Journal of Business Research, 61, 75-82.

Kimpakorn, N. and Tocquer, G. (2010). Service brand equity and employee brand commitment. Journal of Services Marketing, 24, 378-388.

Koçoğlu, C. M. ve Aksoy, R. (2017). Tüketici Temelli Marka Denkliği Bileşenleri Arasındaki İlişkiler Üzerine Bir Araştırma, UIIIID-İJEAS, 18, 71-90.

Kotler, P. (2000) Marketing Management, Upper Saddle River, NJ: Prentice Hall International.

Kotler, P. and Keller, K. L. (2006). Marketing management (12 ed.). Upper Saddle River, NJ: Pearson Prentice Hall.

Lau, G. T. and Lee, S. H. (1999). Consumers' Trust in a Brand and the Link to Brand Loyalty. Journal of Market Focused Management, 4, 341-370.

Lee, S., Jeon, S. and Kim, D. (2011). The impact of tour quality and tourist satisfaction on tourist loyalty: The case of Chinese tourists in Korea. Tourism Management, 32, 1115-1124.

Lehmann, D. R. and Srinivasan, S. (2014). Assessing brand equity through add-on sales. Customer Needs and Solutions, 1(1), 68-76.

Liao, J. K. (2015). The role of trust on brand loyalty and brand equity. Proceedings of the Make Learn and TIIM Joint International Conference, 603-612.

Liu, M., Chu, R., Wong, I. A., Angel Zúñiga, M., Meng, Y. and Pang, C. (2012). Exploring the relationship among affective loyalty, perceived benefits, attitude, and intention to use co-branded products. Asia Pacific Journal of Marketing and Logistics, 24(4), 561-582.

Liu, C. S. and Chou, S. (2016). Tourism strategy development and facilitation of integrative processes among brand equity, marketing and motivation. Tourism Management, 54, 298-308.

Liu, M. T., Wong, I. A., Tseng, T., Chang, W. and Phau, I. (2017). Applying consumer-based brand equity in luxury hotel branding. Journal of Business Research, 81, 192-202.

Liu, C. and Fang, Y. (2018). Conceptualizing, Validating, and Managing Brand Equity for Tourist Satisfaction. Journal of Hospitality \& Tourism Research, 42(6), 960- 978.

Martenson, R. (2007). Corporate Brand Image, Satisfaction and Store Loyalty; A Study of the Store as a Brand, Store Brands and Manufacturer Brands, International Journal of Retail \& Distribution Management, 35(7), 544-555.

Morgan, R.M. and Hunt, S.D. (1994), The commitment trust theory of relationship marketing, Journal of Marketing, 58, 20-38.

Nam, J., Ekinci, Y. and Whyatt, G. (2011). Brand equity, brand loyalty and consumer satisfaction. Annals of Tourism Research, 38(3), 1009-1030.

Namkung, Y. and Jang, S. S. (2013). Effects of restaurant green practices on brand equity formation: Do green practices really matter. International Journal of Hospitality Management, 33, 8595.

Nassar, M. A. (2017). Customer Satisfaction and Hotel Brand Equity: A Structural Equation Modelling Study. Journal of Tourism and Hospitality Management, 5(4), 144-162. 
Olivier, R. L. (1997). Satisfaction: A behavioral perspective on the consumer. New York, NY: McGrawHill.

Pike, S. D. (2009). Destination brand positions of a competitive set of near-home destinations. Tourism Management, 30(6), 857-866.

Pike, S. and Bianchi, C. (2016). Destination brand equity for Australia: Testing a model of CBBE in short-haul and long-haul Markets. Journal of Hospitality \& Tourism Research, 40(1), 114-134.

Pizzutti, C. and Fernandes, D. (2010). Effect of Recovery Efforts on Consumer Trust and Loyalty in E-Tail: A Contingency Model, International Journal of Electronic Commerce, 14(4), 127-160.

Prasad, K. and Dev, C. S. (2000). Managing hotel brand equity. Cornell Hotel and Restaurant, Administration Quarterly, 41(3), 22-31.

Prayag, G., Hosany, S. and Odeh, K. (2013). Theroleoftourists' emotional experiences and satisfaction in understanding behavioral intentions. Journal of Destination Marketing EManagement, 2, 118-127.

Radojevic, T., Stanisic, N. and Stanic, N. (2015). Ensuring positive feedback: Factors that influence customer satisfaction in the contemporary hospitality industry. Tourism Management, 51, 13-21.

Raykov, T. and Marcoulides, A. G. (2006). A First Course Instructural Equation Modeling (2th Edition). New Jersey, USA: Lawrence Erlbaum Inc.

Ribbink, D., Van Riel, A., Liljander, V. and Streukens, S. (2004). Comfort your online customer: quality, trust and loyalty on the internet. Managing Service Quality: An International Journal, 14(6), 446-456.

San Martín, H., Herrero, A. and García de los Salmones, M. M. (2019). An integrative model of destination brand equity and tourist satisfaction. Current Issues in Tourism, 22(16), 1992-2013.

Seric, M., Gil-Saura, I. and Mikulic', J. (2017). Customer-based brand equity building: Empirical evidence from Croatian upscale hotels. Journal of Vacation Marketing, 23(2), 133-144.

Seric, M., Mikulic, J. and Gil-Saura, I. (2018). Exploring relationships between customer-based brand equity and its drivers and consequences in the hotel context. An impact-asymmetry Assessment. Current Issues in Tourism, 21(14), 1621-1643.

Sijoria, C., Mukherjee, S. and Datta, B. (2019). Impact of the antecedents of electronic word of mouth on consumer-based brand equity: a study on the hotel industry. Journal of Hospitality Marketing \& Management, 28(1), 1-27.

Simon, C. J. and Sullivan, M. W. (1993). The Measurement and Determinants of Brand Equity: A Financial Approach, Marketing Science, 12(1), 28-53.

Schumacker, R. E. and Lomax, R. G. (2010). A beginner's guide to structural equation modeling. New York: Taylor \& Francis Group.

Sobel, M.E. (1982). Asymptotic confidence intervals for indirect effects in structural equation models. In: Leinhardt S (ed.) Sociological Methodology. Washington, DC: American Sociological Association, pp. 290-312.

Uslu, A. ve Karabulut, A.N. (2019). Slow Food Konseptine Uygun Restoranlarda, Algilanan Hizmet Kalitesinin, Markaya Yönelik İmaj, Güven ve Sadakate Etkisi: Köyceğiz İlçesini Ziyaret Eden Yabancı Turistler Üzerinde Bir Araştırma. Elektronik Sosyal Bilimler Dergisi, 18(72), 21662181. 
Van Raaij, W. F., Van Veldhoven, G. M. and Wärneryd, K. E. (2013). Handbook of economic psychology. New York, NY: Springer Science \& Business Media.

Vinzi, V.E., Chin, W. W., Henseler, J. And Wang, H. (2010). Editorial: Perspectives on partial least squares In:V.E.Vinzi,W.W.Chin, J. Henseler, \& H. Wang (Eds.), Handbook of Partial Least Squares: Concepts, Methods and Applications (pp: 1-20). Heidelberg, Berlin: Springer-Verlag.

Werts, C. E., Linn, R. L. and Jöreskog, K. G. (1974). Intraclass reliability estimates: Testing structural assumptions. Educational and Psychological Measurement, 34(1), 25-33.

Woo, G.K. and Cha, Y. (2002). Antecedents and consequences of relationship quality in hotel industry. International Journal of Hospitality Management, 21(4), 321-38.

Yoo, B. and Donthu, N. (2001). Developing and validating a multidimensional consumer-based brand equity scale. Journal of Business Research, 52(1), 1-14.

Yoon, S. (2002). The Antecedents and Consequences of Trust in Online-Purchase Decisions. Journal of Interactive Marketing, 16(2), 47-63.

Yuan, J. J. and Jang, S. S. (2008). The effects of quality and satisfaction on awareness and behavioral intentions: Exploring the role of a wine festival. Journal of Travel Research, 46, 279-288.

Zeithaml, V. A. (1988). Consumer perceptions of price, quality, and value: A means-end model and synthesis of evidence. Journal of Marketing, 52, 2-22. 